\title{
Influence of Performance Appraisal on Quality of Service Delivery: A case of Primary Health Care Facilities, Southwestern Nigeria
}

\author{
Adepoju O.O, Opafunso Z.O, Lawal A.F \\ School of Management Technology, Federal University of Technology Akure, PMB 704, Ondo State Nigeria
}

\begin{abstract}
The quality of service delivery at Primary Health Care in Nigeria is considered non satisfactory. One of the factors identified is the substandard performance of the health workers. This paper examines the influence of performance appraisal on health worker's service delivery in Primary Health Care facilities in Nigeria. The study adopted a survey research design with the use of structured questionnaire and in-depth interview to collect data. Multi stage sampling technique was used to sample 241 health workers across the sampled facilities in South-western Nigeria. The data collected was analyzed using descriptive and inferential statistics of statistical package for social science (SPSS version 22). Regression analysis was used to test the hypothesis. The result of the simple regression analysis shows that performance appraisal significantly predict quality health service delivery in PHC at $R$ square $=0.556, p<0.05$ which indicate that performance appraisal accounts for about (55.6\%) of the variability of quality of health service delivery in PHC. The result also indicates a strong positive Beta coefficient of $(\beta=0.746 p<0.05)$. The study concludes that performance appraisal is a common practice in PHC, used mostly for staff promotion. The study therefore recommends regular appraisal of workers' performance, identification of training needs and recognition/reward of staff to encourage better performance.
\end{abstract}

Keywords: Performance Appraisal, Quality Health Service Delivery, Primary Health Care

\section{Introduction}

Quality healthcare delivery is central to a healthy, productive population, as it serve as a contributor to the economic development. The delivery of healthcare is labour demanding in which health workers are the key determinant of health system effectiveness. Health workers are the human resources employed in healthcare system to diagnose health problems, prescribe medications, conduct medical test, care for the sick and educate the people on precautions to take in order to avoid health complications and live a healthy life. Therefore, performance of the health personnel is key to attaining quality in any healthcare delivery system. Primary Health Care (PHC) is widely recognized as the most cost-effective approach of delivering essential health services to the people (WHO, 2008). Primary Health Care is an essential healthcare based on practical, scientifically sound and socially acceptable methods and technology which requires the full participation of the community (WHO, 1978). This is made universally accessible to individuals and families in the community at a cost that the community and country can afford to maintain at every stage of their development in the spirit of self-reliance and self-determination. In Nigeria, PHC was established as the third level of healthcare system under the support and management of the Local Government (Adeyemo, 2006).This level of healthcare system is regarded as the main approach to achieving the national health development plan which includes quality health care through cost-effective interventions, targeted at priority health problems (FMOH, 2004). According to the National Health Policy (2004), healthcare delivery at PHC include maternal, child health care, family planning, immunization against the major infectious diseases, prevention and control of locally endemic and epidemic diseases appropriate treatment of common diseases, injuries and others services. However, it is acknowledge that the quality of service delivered at Primary Health Care facilities in Nigeria is not satisfactory and considered poor (Abimbola, 2012 ; Rasak, 2013). Several challenges have been identified as limiting factors to the effective delivery of quality service. One of the challenges hindering the effectiveness of this healthcare system is human resource constraint (Bangdiwala, Fonn, Okoye and Tollman, 2010; Alenoghena, Aigbiremolen, Abejegah and Eboreime, 2014)). There is absence of effective management of staff performance such as up-todate job descriptions, objectives, targets, supportive supervision, and appraisal mechanisms in Nigeria health sector (FGN, 2007). Accordingly, poor human resource management with the effects of accumulated managerial and clinical care deficiencies are clearly apparent in PHC facilities in Nigeria (Bangdiwala, et al., 2010).There are recorded cases of lack of courtesy of health personnel to patients, lateness of health personnel to work, failure to conduct proper patient examinations and delays in attending to patients (Uneke, Ogbonna, Ezeoha, Oyibo, Onwe, $\mathrm{Ngwu}, 2007)$. Consequently, the function of human resource management plays a major role in monitoring and evaluating employee performance through performance appraisal system. 
Performance appraisal is considered the most significant activity of human resource management (Bekele, Shigutu and Tensay, 2014; Choudhary and Puranik, 2014; Musyoka 2015). It is also an important aspect of human resource development that enables organisation to assess the level of its human resource development, area of needs and devise means of developing their capacity (Mclagan, 1989; Pardue, 2000; Amare 2014).

In recent times, performance appraisal has become a strategic tool in improving effectiveness of health workers and service delivery in health organization (Choudhary and Puranik, 2014; Chegenyea, Mbithib and Musiegac, 2015; Musyoka 2015).This process assists hospitals in monitoring health workers performance, identifying training needs and discovering hidden talents towards developing the health workers capacity to attend to patients concerns and delivery of quality service (Choudhary and Puranik, 2014). To enhance employee development, the employees needs to be aware of their level performance, given constant performance feedback. This will go a long way to reduce uncertainty, anxiety, low productivity and in many cases the loss of a loyal and productive employee (Choudhary and Puranik, 2014). To achieve satisfactory performance of healthcare delivery system in Nigeria, the National Health Policy stipulated monitoring and evaluation of health workers performance as a fundamental activity to be conducted (FMOH, 2004).

Several studies have been conducted on the effect of performance appraisal on employees performance in health sector (Nwema and Gachunga, 2014; Ackah, 2015; Chengeye, et al., 2015; Musyoka, 2015; Sharma and Sharma 2015). Consequently the need for improvement in service delivery in Primary Health Care facilities gave the impetus to conduct this research. This study examined the influence of performance appraisal on health worker's service delivery in Primary Health Care facilities, Southwestern Nigeria. Other objectives are to

(1) To examine the practice of performance appraisal in the Primary Health Care facilities, Southwestern, Nigeria;

(2) To ascertain the use of the performance appraisal review in the study area; and

(3) To determine the influence of performance appraisal practice on quality service delivery in the study area.

\section{Review of Related Literature}

Several authors have presented various definitions of performance appraisal based on their knowledge and experience. Performance appraisal can be defined as the formal assessment and rating of individuals by their managers at, usually, an annual review meeting (Armstrong, 2006). According to Bekele, et al., (2014), performance appraisal is the process of identifying, evaluating and developing the work performance of employees in the organization, so that the organizational goals and objectives are effectively achieved. At the same time, employees are beneficiary of this system as it offers recognition, feedback, career guidance and cater for their work needs. Performance appraisal assist managers to identify workers who are eligible for promotions and salary increments; also help to recognize training and development needs for the workers; at the same time provide feedback required for improvement (Musyoka, 2015). Within the organizational context, appraisal help to judge quality and value which reveals how well an employee performs on the job based on established job measurement criteria (Pardue, 2000). Organisations are expected to establish job standard which would be communicated through job description and measured through the appraisal system. Through this, employee becomes aware of their performance and management takes necessary decisions to ensure that standard is attained.

Mohsin, Mehreen and Saneea (2013) sees performance appraisal as a structured and formal interaction between a subordinate and supervisor, that usually takes the form of a periodic interview (annual or semiannual), in which the work performance of the subordinate is examined and discussed. This is done with the view of identifying weaknesses and strengths, opportunities for improvement and skills development. In addition, information obtained through performance appraisal provides foundations for recruiting and selecting new hires, training and development of existing staff and maintaining a quality work force by adequately and properly rewarding their performance (Choudhary and Puranik, 2014). It also helps in performance feedback, validation of selection process, promotions and transfers, layoff decisions, compensation decisions, human resource planning (HRP), career development and develop interpersonal relationship (Aggarwal and Thakur, 2013).

In general, the basic purpose for performance appraisal system is to improve the employee performance towards ensuring effective and efficient achievement of organizational goals (Adekanbi and Bayat, 2013; Nwenma and Gachunga, 2014). According to Pardue, (2000), a good performance appraisal system is expected to have some basic elements in order to fulfill the organizational and individual aspiration. These include:

(i) Periodical interview of all employees regarding their career progress to assist them in developing their career to the fullest;

(ii) Systematic measure of employee's overall value to the organization; and

(iii) Recording of essential information concerning the strengths and weaknesses of all employees in relation to career development, potential for advancement and training. 


\section{Techniques of Performance Appraisal in PHC}

There are several methods of conducting performance appraisal. According to Aggarwal and Thakur, 2013, these methods are broadly classified into traditional and modern techniques of Performance Appraisal. The traditional methods are older methods of performance appraisal based on studying the personal qualities such as knowledge, initiative, loyalty, leadership and judgment of the employees. These methods include Ranking, Graphic Rating Scale, Critical Incident and Narrative Essay, Forced Choice, Field Review and performance Test and Observation. On the other hand, the modern methods are developed to improve on the limitations of the traditional methods. These methods assess the capability of an employee to perform well in the future and assist to set future organizational objectives. They include self-appraisal, management by objectives, behaviorally anchored rating scale, 360 degree, 720 degree, human resource accounting and cost Accounting (Aggarwal and Thakur, 2013; Mohsin, Mehreen and Sanreea, 2013).

In Nigeria healthcare system, performance appraisal is conducted through the use of an appraisal form and a written examination. The appraisal form includes information on employer's expectation of individual staff in terms of skills, knowledge, attitude, training acquired and career development. This method of appraisal is a ratings scale that lists required number of traits and a range of performance expectations which is use to evaluate the employee. This is done by assigning scores that best describes the employees' performance for each trait (Aggarwal and Thakur, 2013). This is a simple method which is easily constructed and the results are standardized for comparison between the employees. Employees are assessed for performance attainment based on the information provided in the self completed appraisal form (Adekanmbi and Bayat, 2013).The written examination is conducted as a complement to the appraisal form, to assess the present state of knowledge of the employee on the job.

\section{Purpose of Performance Appraisal in Healthcare}

In the healthcare sector, performance of health workers is the backbone of quality service delivery (Chegenyea, et al., 2015). The primary objective of performance appraisal is to optimize the quality of work and improve the quality of healthcare delivery (Choudhary and Puranik, 2014). Healthcare facilities are expected to develop a method of assessing the skills, knowledge and attitudes required by healthcare service providers. This criterion serves as a standard in judging how well the health personnel perform and also identifies areas of improvement. Therefore, establishing performance appraisal program in the hospital helps the management to monitor employees' performance, and also motivates staffs by improving their morale which translates to improved quality of healthcare practice (Choudhary and Puranik, 2014; Musyoka, 2015). According to Ashian and Zachary (2004), performance appraisal is a required practice for health organisations to:

(i) correct performance by identifying areas that needs improvement and steps can be taken to foster improvement;

(ii) promote improved career planning designed to assist in the advancement of the employee to reach his/her potential; and

(iii) provide documentation for making personnel decision such increment, advancement and termination demonstrate fairness on the part of the employer.

Consequently, the result from the appraisal exercise informs employees' of their area of strengths and weaknesses which are intended to improve their performance. Moreover, problems encountered by employees in the discharge of their responsibilities are identified through appraisal system which serves as a basis for recommendation for training. Consequently, performance appraisal in healthcare system is important because it keeps health workers informed of their performance which assists them in identifying areas of deficiency towards improving the quality of service delivered to patient.

\section{Quality Service Delivery in Healthcare}

There is an increasing demand for high quality service in healthcare system over the world. The evaluation of quality service in the health sector started by a U.S surgeon, Ernest Codman which led to the founding of the American College of Surgeons and the Joint Commission on Accreditation of Health Organizations (JCAHO) (Petrik, 2004). In a service industry, like healthcare, experience of patients plays a crucial role in assessing quality of services (Wanjau and Muiruri, 2012). Quality healthcare service is giving patients what they want (patient quality) and what they need (professional quality) and expending lesser resources while doing so. This should be done without errors, delays, waste of resources and within higher level regulations (Overtreit, 1992) cited by (Kumaraswamy 2012). Parasurman et al. (1985) developed a measurement tool known as SERVQUAL for service quality which has been empirically proven to be useful in healthcare settings in developing countries (Boshoff and Gray, 2004; Kumaraswamy, 2012; Wesso, 2014). This tool stipulates five dimensions (tangibles, reliability, responsiveness, assurance and empathy) by which service quality is evaluated in relation to patient's satisfaction. 


\section{Empirical Literature Review}

Several empirical studies reveal that performance appraisal influence employee performance. Musyoka (2015) carried out a study on the influence of performance appraisal on health workers performance in public hospitals: case of Mbagathi hospital, Kenya. The study adopted a cross sectional descriptive and exploratory research design using purposive and stratified sampling technique to survey 179 respondents. The results of the findings indicated that performance has a mean score $57.6 \%$, performance appraisal was poorly implemented and it was minimally used for training and promotion and not used in rewarding and feedback.

Bekele, et al., (2014), in their study titled “'The Effect of Employee's Performance of their Work Outcome" examined the perception of performance appraisal practice on employee work performance. Stratified and simple random sampling technique was applied to select a sample of 119 employees from the total population of 202 employees. The result indicates employees' perception of performance appraisal practice had positive correlation $(\mathrm{r}=.411, \mathrm{p}<0.01)$ with employees' work performance.

This study of Nwema and Gachunga (2014) on the influence of performance appraisal on employee productivity in organizations: Descriptive design was adopted and sample size of 105 was used in this study. The data was gathered through the use of questionnaires and interview. The data collected was analyzed using regression analysis of SPSS. The result of the findings shows that performance appraisal on employees has positive effects on employee's productivity which is statistically significant with a P-Value of 0.004 and 0.002 at 95\% confidence level. Ackah (2015) carried out a study titled 'Performance Appraisal and its Effects on Employee Performance in Ghana Health Service. Fifty respondents were sampled using convenient sampling technique. Data collected from the primary source (questionnaires) were exported to Microsoft excel (2010) for data transformation, running of cross tabulations and percentages. The result of the findings shows that there exists a valid relationship between performance appraisal and employee productivity.

Sharma and Sharma (2015) carried out a study on an impact of private hospitals appraisal system on healthcare provider in jaipur-rajasthan. In this study, 60 samples were selected using simple random sampling technique form the total employees in the private hospitals in jaipur-rajasthan. The finding of the study indicates that performance appraisal has helped in increasing the performance of Private hospitals employees.

Chengeye, et al., (2015) carried out a study on the Role of Performance Management System on Service Delivery, Case Study of Kakamega County General Hospital, Kenya. In this study, three hundred (300) permanent health workers were selected using stratified, simple and purposive random sampling technique were employed to pick the respondents who participated in the study. The study revealed that performance target setting has high positive relationship with service delivery at $r=0.544, p=0.000$, hence $p<0.005$ at the hospital.

\section{Methodology}

The study adopted a cross-sectional survey design among health workers and service utilizers in the selected Primary Health Care facilities sampled in Southwestern States of Nigeria. The study population comprised the health care workers and the patients selected in sampled health care facilities, Southwester Nigeria. The health workers include the doctors, nurses, midwives community health extension workers (CHEW), pharmacist technician, lab technician and medical records officers with a sample size of 241 and 239 patients were purposively selected for the study. Data collected was derived through a structured questionnaire and an in-depth-interview of key personnel in the health care facilities. The data was analysed using descriptive and inferential statistics. The descriptive statistical analysis involved the use of table and chart which showed the percentage distribution of the socio-demographic variables and descriptive analysis of the research findings. The inferential statistics used the simple linear regression to determine the predictive influence of performance appraisal practice on health worker's service delivery.

\section{Socio Demographic Characteristics}

\section{Result and Discussion}

The demographic characteristics of the respondents shows that majority $197(81.1 \%)$ of the respondents were female while 44(18.9\%) were male. Most of the respondents $106(44.0 \%)$ were in the age category of 40 years and above. The educational qualification of the respondents revealed that most of the respondents 104(43.2\%) were HND holders, 96(39.6\%) were diploma/OND holder, 22 (9.1\%) had Bachelor's degree, $7(2.9 \%)$ had senior secondary certificate examination qualification, $6(2.5 \%)$ were certificate and masters holders respectively. On designation, most $86(35.7 \%)$ of the service providers that participated in the study were community extension workers, $58(24.1 \%)$ were nurses, 30(12.4\%) were lab technician and medical records officers respectively, $27(11.2 \%)$ were pharmacist technician and 10(4.1\%) were medical doctors. The work experience of the respondents shows that that majority $198(82.1 \%)$ of the service providers have worked in the health facilities for four (4) years and above, $30(12.4 \%)$ of the respondents have between 1 to 3 years, $13(5.4 \%)$ have less than a year working experience. 


\section{Existence of Appraisal Exercise in Primary Health Care Facilities}

Table 1 presents the number of respondents that indicated the existence of appraisal exercise in the health care facilities. Majority $(n=219 ; 91.9 \%)$ of the service providers claimed the existence of performance appraisal exercise in their facilities while few $(\mathrm{n}=22 ; 9.1 \%)$ indicated no appraisal exercise. From the result, one can infer that performance appraisal is a practice in Primary Health Care.

Table 1: The Existence of Performance Appraisal Exercise in Primary Health Facilities, Southwestern Nigeria

\begin{tabular}{|l|l|l|}
\hline Is performance appraisal exercise carried out in your PHC facility & Frequency & Percentage \\
\hline Yes & 219 & 90.9 \\
\hline No & 22 & 9.1 \\
\hline Total & $\mathbf{2 4 1}$ & $\mathbf{1 0 0 . 0}$ \\
\hline
\end{tabular}

Source: Field Survey (2016)

\section{Use of Performance Appraisal in Primary Health Care}

Figure 1 present the result on the use of performance appraisal in the Primary Health Care facilities. Most ( $\mathrm{n}=158 ; 72.1 \%)$ of the respondents reported that performance appraisal is use for promotion. Ninety six respondents $(43.8 \%)$ reported that performance appraisal is used for training. About $37 \%(\mathrm{n}=81)$ of the service providers reported that performance appraisal is use for salary increment. Few $(n=39 ; 17.8 \%)$ of the service providers reported that performance appraisal is use for Award/Recognition of outstanding staff. The in-depthinterview revealed that performance appraisal is majorly conducted for the purpose of staff promotion.

From the findings, one can infer that performance appraisal is majorly used for promotion, fairly used for recommending staff for training and barely used for rewarding health workers. This is in line with the study of Lutwama et al., (2013) which revealed that (80.4\%) of the health workers confirm that performance appraisal is mostly use for promotion, $79.7 \%$ indicated the use of performance appraisal for identifying training needs and $69.6 \%$ indicated for rewarding health workers.

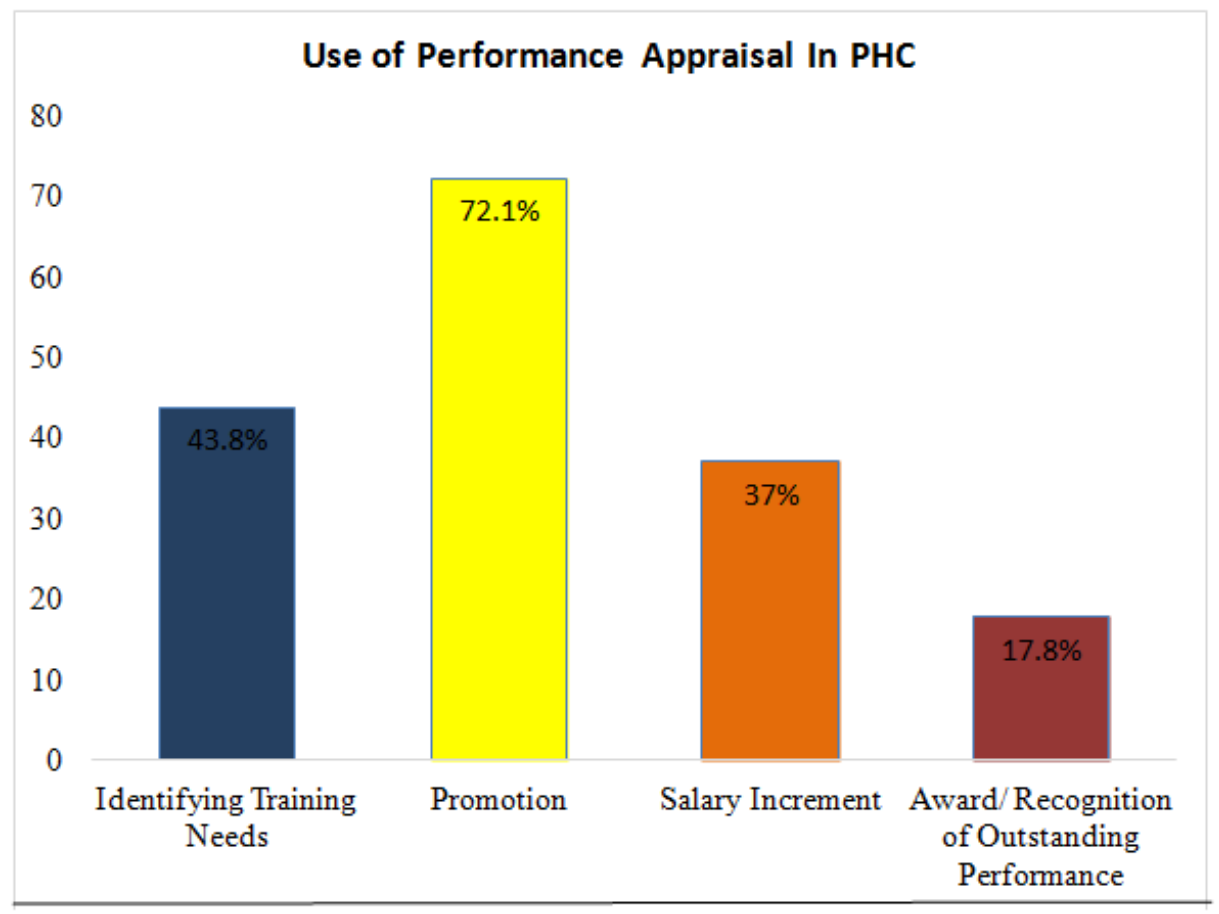

Figure 1: Use of Performance Appraisal in PHC

From the findings, performance appraisal is majorly used for promotion, fairly used for recommending staff for training and barely used for rewarding health workers (Figure 1). This is in line with the study of Lutwama et al., (2013) which revealed that (80.4 per cent) of the health workers confirm that performance appraisal is mostly use for promotion, 79.7 per cent indicated the use of performance appraisal for identifying training needs and 69.6 per cent indicated for rewarding health workers. 


\section{Frequency in Performance Appraisal Exercise in the Study Area}

Figure 2 present the result on the frequency in the performance appraisal exercise conducted at the PHC facilities. From the result, most of the respondents ( $\mathrm{n}=156 ; 71.2 \%$ ) indicated Annual appraisal, $21 \%$ (46) indicated appraisal done on Quarterly basis, 11\% ( $\mathrm{n}=24)$ selected Bi-Annually (six month), 17.8\% ( $\mathrm{n}=39)$ indicated that appraisal is carried out every two years and $17.8 \%$ (19) indicated No appraisal.

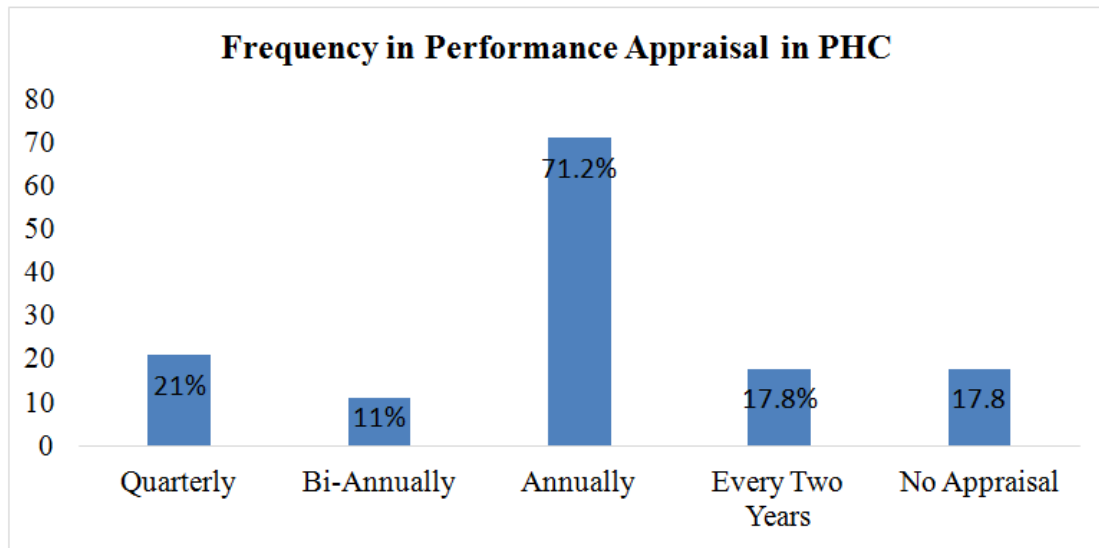

Figure 2: Frequency in Performance Appraisal Exercise in Primary Health Care

From the findings, performance appraisal is conducted mostly on annual basis in Primary Health Care.

\section{Perception of Health Workers on the Performance Appraisal Practice in PHC}

Table 4 present the results on the performance appraisal practice as perceived by the service providers in Primary Health Care facilities. These variables were evaluated on a five point likert scale: strongly agree (5), agree (4), undecided (3), disagree (2), and strongly disagree (1). The responses were analysed by percentage and mean. The mean score was interpreted by the likert scale point. The results shows that the respondents agreed that PHC conduct a formal and written appraisal system (mean 4.18), respondents agreed that performance appraisal form is well understood (mean 4.23), respondents agreed that they receive feedback on their performance evaluation (mean 3.88), respondents agreed that the supervisor often discuss the feedback with the staff (mean 3.69), respondents agreed that the feedback receive enhance their service delivery (mean 3.90), respondents agreed that performance is measured on the basis of their skill; knowledge and attitude to the patients (mean 4.24), respondents agreed that performance appraisal exercise contribute to better service delivery (mean 3.89) and respondents agreed that performance appraisal help to improve relationship with supervisor (supervisee) (mean 4.20). The result revealed that the service providers agreed to a good practice of performance appraisal (mean 4.02)

The in-depth interview revealed that PHC adopt a formal appraisal with the use of appraisal form and a written test. The appraisal form is used to assess the health worker's discharge of responsibilities, career development, training acquired, communication and interpersonal skills and areas of employee training needs, while the written method is conducted to assess the knowledge of the health workers. From the report, employees receive feedback on performance review and coaching is organised for employee in areas of shortcomings, which has helped to enhance the quality of service delivery. This is line with Nwema and Gachunga (2014) which revealed that feedback received improved the productivity of the employee.

Table 4: Perception of Health Workers on Performance Appraisal Practice in PHC

\begin{tabular}{|c|c|c|c|c|c|c|}
\hline Performance Appraisal Practice in PHC & $\begin{array}{l}\text { Strongly } \\
\text { Agree }\end{array}$ & Agree & Undecided & Disagree & $\begin{array}{l}\text { Strongly } \\
\text { Disagree }\end{array}$ & Mean \\
\hline \multicolumn{7}{|c|}{ \% Response } \\
\hline PHC conduct a formal and written appraisal system & 43.2 & 41.5 & 8.3 & 3.7 & 3.3 & 4.18 \\
\hline Understand how to fill the performance appraisal form & 53.9 & 31.1 & 3.7 & 7.1 & 4.1 & 4.23 \\
\hline Receive feedback on performance evaluation & 34.7 & 41.6 & 4.6 & 15.4 & 3.7 & 3.88 \\
\hline Supervisor often discuss the feedback with the staff & 49.8 & 13.3 & 2.1 & 26.6 & 8.3 & 3.69 \\
\hline Feedback receive enhance their service delivery & 41.5 & 34.4 & 3.3 & 14.5 & 6.2 & 3.90 \\
\hline $\begin{array}{l}\text { Performance is measured on the basis of skill; } \\
\text { knowledge and attitude to the patients }\end{array}$ & 43.2 & 46.5 & 4.1 & 3.3 & 2.9 & 4.24 \\
\hline $\begin{array}{l}\text { Performance appraisal exercise contribute to better } \\
\text { service delivery }\end{array}$ & 13.7 & 74.7 & 2.9 & 4.6 & 4.1 & 3.89 \\
\hline $\begin{array}{l}\text { Performance appraisal help to improve relationship } \\
\text { with supervisor (supervisee) }\end{array}$ & 44.8 & 41.5 & 5.8 & 5.0 & 2.9 & 4.20 \\
\hline Total & & & & & & 4.02 \\
\hline
\end{tabular}

Source: Field Survey (2016) 


\section{Result on Quality Service Delivery}

Quality Service delivery at Primary Health Care was determined based on five factors used to measure the satisfaction of the patients on the service delivery. This is based on a measurement tool known as SERVQUAL for service quality which was developed by Parasurman, Berry and Zeithaml (1985) and has been empirically proven to be useful in healthcare setting in developing countries. These include:

(i) Tangibles: clean and hygienic working environment;

(ii) Courtesy and respect;

(iii) Precision: illness diagnosis precision;

(iv) Responsiveness: prompt delivery of service;

(v) Empathy: care; and

(vi) Competency: workers display of skill.

The result of the measure of quality of service delivery (Table 5) revealed that the respondents agreed that the environment of the primary health care facility is hygienic and kept clean for delivery of service (mean 4.13 ), respondents agreed that the health workers treated them with courtesy and respect (mean 4.65), respondent agreed that the right medical conditions were diagnosed and treated (mean 4.29), respondent agreed that during their visit they were attended to on time (mean 4.04), the respondents agreed that during their visit the health workers showed care and listened carefully to their complaint (mean 4.62), the respondent agreed that the staff demonstrated competency on their job (mean 4.59). Overall, the result revealed that the patients are satisfied with the quality of service delivered by the health workers in the PHC facilities.

Table 5: Perception of the Patient on the Quality of Service Delivery

\begin{tabular}{|c|c|c|c|c|c|c|}
\hline Measure of Quality Service Delivery & $\begin{array}{c}\text { Strongly } \\
\text { Agree }\end{array}$ & Agree & Undecided & Disagree & $\begin{array}{l}\text { Strongly } \\
\text { Disagree }\end{array}$ & Mean \\
\hline $\begin{array}{l}\text { The environment of the primary health care facility is } \\
\text { hygienic and kept clean for delivery of service }\end{array}$ & 46.0 & 37.7 & 1.7 & 12.6 & 2.1 & 4.13 \\
\hline $\begin{array}{l}\text { During my visit the health workers treated me with } \\
\text { courtesy and respect }\end{array}$ & 68.2 & 30.1 & 0.0 & 1.7 & 0.0 & 4.65 \\
\hline The right medical conditions were diagnosed and treated & 45.6 & 37.7 & 16.7 & 0.0 & 0.0 & 4.29 \\
\hline During my visit, I was attended to on time & 46.4 & 33.5 & 0.0 & 18.0 & 2.1 & 4.04 \\
\hline $\begin{array}{l}\text { During my visit the health workers showed care and } \\
\text { listened carefully to my complaint }\end{array}$ & 64.0 & 34.7 & 0.0 & 1.3 & 0.0 & 4.62 \\
\hline $\begin{array}{l}\text { The staff at the PHC demonstrated competency on their } \\
\text { job. }\end{array}$ & 60.7 & 38.1 & 0.8 & 0.0 & 0.4 & 4.59 \\
\hline
\end{tabular}

Source: Field Survey (2016)

\section{Hypothesis}

Ho: Performance appraisal practice does not significantly influence the quality of service delivery in Primary Health Care

$\mathbf{H}_{1}$ : Performance appraisal significantly influence the quality of service delivery in Primary Health Care

\section{Result and Discussion}

Simple regression analysis was used to test the predictive influence of performance appraisal on quality of service delivery in PHC. The result of the regression model shown in table 4 indicates the value of the regression coefficient $\mathrm{R}=.746 \mathrm{R}$, square $=.556$ and significance level of $\mathrm{P}=0.000$ indicates that the model is significant at $\mathrm{p}<0.05$, two tailed. The predictive influence of performance appraisal of health workers on quality service delivery is explained by the value of $\mathrm{R}$ square $=0.556$ which indicate that performance appraisal" accounts for about 55.6 per cent of the variability of "quality of service delivery". in Primary Health Care. The result also indicates a strong positive Beta coefficient of $(\beta=0.678 \mathrm{p}<0.05)$. The beta coefficient $(\beta$ $=.678$ ) implies that quality service delivery is increased by 67.5 per cent, if the performance appraisal practice (Satisfaction) increases by 1 . This result shows that performance appraisal significantly influence quality of service delivery in PHC. Hence the null hypothesis is rejected while the alternate hypothesis is accepted.

This supports the findings of Ackah (2015); Bekele et al., (2014); Nwema and Gachunga (2014); Igbal et al., (2013) which states that performance appraisal has a positive influence on employee performance which ultimately affect the organizational performance. 
Table 6. Simple Regression Analysis of Quality Service Delivery on Performance Appraisal

\begin{tabular}{|l|r|r|r|r|}
\hline Model Summary & \multicolumn{1}{|l|}{ Std. Error of the Estimate } \\
\hline Model & R & R Square & Adjusted R Square & Std \\
\hline 1 & $.746^{2}$ & .556 & .554 & .510 \\
\hline
\end{tabular}

a. Predictors

b. Dependent Variable

\begin{tabular}{|c|c|c|c|c|c|c|c|}
\hline \multirow[t]{2}{*}{ Model } & \multicolumn{2}{|c|}{$\begin{array}{l}\text { Unstandardized } \\
\text { Coefficients }\end{array}$} & $\begin{array}{l}\text { Standardized } \\
\text { Coefficients }\end{array}$ & \multirow[t]{2}{*}{$\mathrm{t}$} & \multirow[t]{2}{*}{ Sig. } & \multicolumn{2}{|c|}{$\begin{array}{l}95.0 \% \text { Confidence Interval } \\
\text { for B } \\
\end{array}$} \\
\hline & B & Std. Error & Beta & & & Lower Bound & Upper Bound \\
\hline (Constant) & .096 & .089 & & 1.089 & .277 & -.078 & .271 \\
\hline $\begin{array}{l}1 \text { Performance } \\
\text { appraisal }\end{array}$ & 675 & .039 & .746 & 17.303 & .000 & .598 & .752 \\
\hline
\end{tabular}

Dependent Variable

\section{Conclusion}

Based on the findings, the following conclusions were drawn. Performance appraisal is an important practice of accessing health workers performance in PHC. This appraisal system is mostly conducted on a yearly basis to access the health workers performance. Performance appraisal review in PHC is mostly used for promotion, fairly used for recommending staff for training and barely used for rewarding health workers. There is a positive perception of the health workers regarding the practice of performance appraisal in the healthcare system. A written and a rating method of appraisal are adopted in the healthcare system. This avails the opportunity to access the skills, knowledge and attitude of the health personnel. Feedback on the appraisal review helps the health workers to discover areas of shortcomings that require improvement for better performance. Consequently the feedback received motivates the health workers and help to improve on the quality of service delivery. The result on the simple regression analysis reveals that performance appraisal significantly influence quality of service delivery in PHC. Based on the findings it is recommended that appraisal of health workers' performance should conducted on a regularly basis and at interval times other that the yearly appraisal. Also, appraisal review should be used more often for identification of training needs to elevate health worker's performance, empower them to attend to patients needs and discovery of hidden talent which will helps to improve the quality of healthcare delivery in PHC.

\section{Reference}

[1]. Abimbola, S. (2012, May). How to improve the Quality of Primary health care in Nigeria. An online artivle fro Nigerianstalk. Retrieved on $20^{\text {th }}$ February, 2014 from http://nigerianstalk.org

[2]. Ackah. (2015, December 10). Performance Appraisal and its Effect on Employee Performance in Ghana Health Service. Retrieved July 25, 2016, from Linkedlin: http://www.linkedin.com/pulse/performanceappraisal

[3]. Adekanmbi, A. B., and Bayat, M. S. (2013). Performance Management and Development Systems with Balanced Scorecard as a Performance Appraisal Tool at a Selected Eastern Cape Hospital: A case study Approach. Singaporean Journal of Business Economics and Management Studies , 1-11.

[4]. Aggarwal, A., and Thakur, G. (2013). Techniques of Performance Appraisal: A Review. International Journal of Engineering and Advance Technology , 2 (3), 617-621.

[5]. Alenoghena, I., Aigbiremolen, A., Agbejegah, C., \& I, E. E. (2014). Primary Health Care in Nigeria: Strategies and Constraint in Implementation. International Journal of Community Research , 2 (2), 74-79.

[6]. Amare, S (2014) Human Resource Development Practices and Challenges in Public Sector: Evident from selected Regional Public Bureaus in Tigray, Unpublished Thesis Department of Management, Makelle University, Ethiopia.

[7]. Armstrong, M. (2006). Human Resource Management Practice. London, United Kingdom: Kogan Page Limited.

[8]. Ashian, D., and Zachary, D. (2004). Utilization of Performance Appraisal System in Health Care

[9]. Organisations and Improvement Strategies for Supervisors. Journal of Health Care Manager, 23 (1) 25-30

[10]. Bangdiwala, S., Fonn, S., Okoye, O., and Tollman, S. (2010). Workforce Resources for Health in Developing Countries. Journal of Public Health Review , 32, 296-318.

[11]. Bekele, A. Z., Shigutu, A. D., and Tensay, A. T. (2014). The Effect of Employees' Perception of Performance Appraisal on their Work Outcome. International Journal of Management and Commerce Innovations , 2 (1), 136-173.

[12]. Boshoff, C., and Gray, B. (2004). The Relationship Between Service Quality, Customer

[13]. Satisfaction and Buying Intentions in the Private Hospital Industry. South African Journal of Business Management , 35 (4), 27-37.

[14]. Choudhary, G. B., \& Puranik, S. (2014). Study on Employee Performance Appraisal in Health care. Asian Journal of Management Sciences , 2 (3), 59-64.

[15]. Chegenyea, J., Mbithib, S., and Musiegac, D. (2015). Role of Performance Management System on Service Delivery, Case Study of Kakamega Country General Hospital, Kenya. International Journal of Sciences: Basic and Applied Research , 23 (1), 437-451.

[16]. FGN. (2007). National Human Resources for Health Strategic Plan (2008-2012). Abuja: Federal Government of Nigeria.

[17]. FMOH. (2004). Revised National Health Policy. Abuja: Ministry of Health.

[18]. Kumarasmy, S. (2012). Service Quality in Health care Center: An Empirical Study . International Journal of Business and Social Science, 3 (16), 141-150. 
[19]. McLean, G. (2005). Organisational Development Principles Processes Performance. USA: Berrett-Koehler.

[20]. Mohsin, A., Mehreen, S., and Saneea, H. (2013,April 25th). The Effect of Performance

[21]. Evaluation on Employee's Job Satisfaction in Pakistan International Airlines.

[22]. Musyoka. (2015). Performance Appraisal Influence on health Worker's Performance in Public Hospitals: A Case Study of Mbaghati Hospital in Kenya. Journal of Global Health Care System , 5 (3).

[23]. Mwema, N. W., and Gachunga, H. C. (2014). The Influence of Performance Appraisal on

[24]. Employee Productivity in Organisations: A Case Study of Selected WHO Office East Africa. International Journal of Social Science and Entrepreneurship , 1 (11), 324-337.

[25]. Parasurman, A., Berry,L \& Zeithaml, V. (1985). A Conceptual Model for Service Quality and Its

[26]. Implication for Future Research. Journal of Marketing Research , 49 (4), 41-50.

[27]. Pardue, H. M. (2000). Performance Appraisal as an Employee Development Tool. Society for Human Resource and Management Research.

[28]. Petrick, J. F. (2004). The Role of Quality, Value and Satisfaction in Predicting Cruise

[29]. Passengers' Behavioral Intentions. Journal of Travel Research, 42 (4), 397-407

[30]. Rasak, O. (2013). Patrons' Perception of Quality of Healthcare Services in Primary Health Care

[31]. Centres in Oyo State, Nigeria. Journal of Developing Countries, 3 (1), 75-83.

[32]. Uneke, C., Ogbonna, A., Ezeoha, A., Onwe, F., \& Ngwu, B. (2007). The Nigeria Health Sector

[33]. and Human Resource Challenge. Internet Journal of Health , 8 (1).

[34]. Wesso, A. (2014). The Perceived Quality of Healthcare Services and Patients Satisfaction in

[35]. South African Public Hospitals. South Africa: Unpublished Thesis, Faculty of Economics, University of Ljblajana.

[36]. WHO. (1978). Primary Health Care: Report on International Conference on Primary Health

[37]. Care, Alma-Ata. Geneva: World Health Organisation

[38]. WHO. (2008). Primary Health Care Now More than Ever . Geneva: World Health Organization. 